\section{Study of Water Quality and its Health Effects DUE TO INDUSTRIALIZATION IN NOAPARA AND ChHATIAIN Union Of HabiganJ, Bangladesh}

\author{
Tanje-Un-Jenat ${ }^{a}$, Md. Tariqul Islam $^{a^{*}}$, Md. Jahir Alam $^{b}$ \\ aDepartment of Geography and Environment, Shahjalal University of \\ Science and Technology, Sylhet \\ ${ }^{b}$ Department of Civil and Environmental Engineering, Shahjalal \\ University of Science and Technology, Sylhet
}

Article history Received

5 June 2020

Received in revised form

13 September 2020

Accepted

15 September 2020

Published online

30 November 2020

*Corresponding author islam-gee@sust.edu

\begin{abstract}
In this paper, an attempt has been taken to assess the water quality and its impact on local inhabitants along with their hea lth problems due to industrialization without treatment plant in Noapara and Chhatiain Union of Habiganj. To assess the water quality, physico-chemical analysis of water was carried out based on their importance in different usage. Water samples of different locations have DO in the ranges of $2.1 \mathrm{mg} / \mathrm{l}$ to $9.8 \mathrm{mg} / \mathrm{l}$. According to WQI, during dry period, about $42 \%$ water samples are ranked as "Unsuitable" whereas $28.5 \%$ as "Excellent" during monsoon.CDI value from dermal absorption was evaluated using USEPA guidelines and found the highest amount as $140 \mathrm{mg}$ and $150 \mathrm{mg}$ for children and adult respectively for only elements related with nitrate and ammonia.
\end{abstract}

Keywords: Corn starch, Poultry feed, Industrial effluent, Water Quality Index, Dermal absorption

(C) 2020 Penerbit UTM Press. All rights reserved

\subsection{INTRODUCTION}

Industrialization without treatment plant causes the impediment of the natural drainage system, which substantially reduces its water quality. In order to cope with the excessive demographic pressure and increasing demand for more job opportunities, the Government of Bangladesh is going to establish more industrial zones. But unplanned industrialization and urbanization cause environmental pollution with degrading the water quality of water bodies [1], [2], [3], [17]. Jafarzadeh et al. [15] tested water parameters of water bodies of industrial zone in Khuzestan Province in Iran and results indicate that waste water imposes degradable organic substances and suspended particle loads to river. Since it is very difficult to assess the water quality only based on parameters' concentration, Water Quality Index (WQI) is globally used in measuring the overall pollution status of water in a drainage system[10], [18].

In this study, industries located in Noapara Union of Habiganj district have been considered to understand the impact of industrialization without treatment plant in nearby rural areas - Noapara and Chhatiain Union, as no such attempt on this regard has been taken before in this area. To achieve this goal, industries have been evaluated based on the intensity of water quality parameters of surrounding water bodies; corresponding consequences of affected ecosystems has been detected; overall suitability of those water in dry and monso on season for different usage have been calculated based on WQI value; and health effects of local inhabitants depended on those water have been assessed based on WQI and Dermal Absorption.

\subsection{METHODOLOGY}

\subsection{Determination of Water Sample Parameters}

Sample bottles were washed with 1:3 HNO3 acid before sample collection and samples were randomly collected from 14 sample sites during dry and rainy seasons in $2.5 \mathrm{~L}$ plastic containers following APHA (1995) method [4]. Among those 14 
sample sites - W2, W5 and W9 were located at the discharge point; and W3 was located at an embankment (Figure 8 and Figure 1). Samples were tested in two different ways, some were with the help of instrument and some were manually in laboratory detailed in Table 1.

Table 1 Illustration of procedures for sample analysis

\begin{tabular}{|c|c|c|c|}
\hline Parameters & Instrument & Model & Method \\
\hline $\mathrm{pH}$ & HANNA & HI 9125 & \\
\hline $\begin{array}{l}\text { Dissolve } \\
\text { Oxygen (DO) }\end{array}$ & Lutron & $\begin{array}{l}\text { DO-5509; YK- } \\
\text { 22DO }\end{array}$ & \\
\hline $\begin{array}{l}\text { Biochemical } \\
\text { Oxygen } \\
\text { Demand } \\
\text { (BOD) }\end{array}$ & 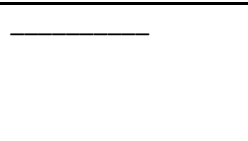 & & \\
\hline $\begin{array}{l}\text { Chemical } \\
\text { Oxygen } \\
\text { Demand } \\
\text { (COD) }\end{array}$ & 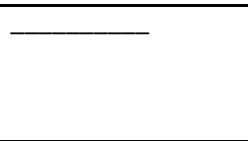 & & Titration \\
\hline $\begin{array}{l}\text { Ammonia } \\
\left(\mathrm{NH}_{3}-\mathrm{N}\right)\end{array}$ & $\begin{array}{lr}\mathrm{HACH} & \text { (UV- } \\
\text { Spectrophotometer }\end{array}$ & DR 6000 & Nessler \\
\hline $\begin{array}{l}\text { Nitrate } \\
\left(\mathrm{NO}_{3}-\mathrm{N}\right)\end{array}$ & $\begin{array}{lr}\mathrm{HACH} & \text { (UV- } \\
\text { Spectrophotometer) }\end{array}$ & DR 6000 & $\begin{array}{l}\text { Cadmium } \\
\text { Reduction }\end{array}$ \\
\hline $\begin{array}{ll}\begin{array}{l}\text { Total } \\
\text { (TS) }\end{array} & \\
\end{array}$ & Hot Air Oven & & - \\
\hline $\begin{array}{l}\text { Total } \\
\text { Suspended } \\
\text { Solid } \\
\text { (TSS) }\end{array}$ & Hot Air Oven & & \\
\hline $\begin{array}{l}\text { Total } \\
\text { Dissolve } \\
\text { Solid } \\
\text { (TDS) }\end{array}$ & Hot Air Oven & 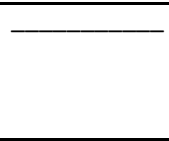 & \\
\hline Turbidity & HANNA & HI 93703 & 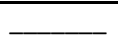 \\
\hline
\end{tabular}

Source: Laboratory Analysis, 2019

\subsection{Calculating WQI}

In this study, WQI is determined using the following formula [5]:

$\mathrm{Wi}=\mathrm{k} / \mathrm{Si} \ldots \ldots \ldots(1)$

Where, $\mathrm{Si}$ is standard permissible value of ith water quality parameter and $\mathrm{k}$ is constant of proportionality and it is calculated by using the expression:

$k=[1 /(\Sigma 1 / S i=1,2, . . i)]$

Subsequently, calculation of WQI was carried out using the expression given in Equation (3).
$W Q I=\Sigma Q_{i} * W i / \Sigma W i$

Where, Qi is quality rating of ith water quality parameter and $\mathrm{Wi}$ is unit weight of ith water quality parameter. The quality rating $(\mathrm{Q} i)$ is calculated using the expression given in Equation (4).

$Q i=[(V i-V i d) /(S i-V i d)] \times 100$

Where, $\mathrm{Vi}$ is estimated value of ith water quality parameter at a given sample location, Vid is ideal value for ith parameter in pure water (note: Vid for $\mathrm{pH}=7, \mathrm{DO}=14.6$, and 0 for all other parameters) and $\mathrm{Si}$ is standard permissible value of ithwater quality parameter. To generate changes in WQI along the study area, interpolation was used.

Indiscriminate dumping of solid and liquid industrial waste into the natural environment significantly alters the aquatic ecosystem. A comparison of water quality change with the standards may depict the whole scenario. Bangladesh Drinking Water Standards (BDWS), Department of Environment (DOE) and Environment Conservation Rule (ECR, 1997) standards for aquatic ecosystem have been listed below (in Table 2).

Table 2 Standard values for water parameters

\begin{tabular}{|c|c|c|c|c|c|c|}
\hline \multirow[t]{2}{*}{ Parameters } & \multirow[t]{2}{*}{ BDWS } & \multirow[t]{2}{*}{ DoE } & \multicolumn{4}{|c|}{ ECR } \\
\hline & & & Fisheries & $\begin{array}{l}\text { Irrigatio } \\
\mathrm{n}\end{array}$ & Drinking & $\begin{array}{l}\text { Recreation } \\
\text { al }\end{array}$ \\
\hline $\mathrm{pH}$ & $\begin{array}{l}6.5- \\
8.5\end{array}$ & $\begin{array}{l}6.5- \\
8.5\end{array}$ & $6.5-8.5$ & $6.5-8.5$ & $6.5-8.5$ & 6-9.5 \\
\hline $\mathrm{DO}(\mathrm{mg} / \mathrm{L})$ & 6 & 5 & $\begin{array}{l}5 \text { or } \\
\text { more }\end{array}$ & $\begin{array}{l}5 \text { or } \\
\text { more }\end{array}$ & $\begin{array}{l}5 \text { or } \\
\text { more }\end{array}$ & $4-5$ \\
\hline $\mathrm{BOD}(\mathrm{mg} / \mathrm{L})$ & 0.2 & 2 & 6 or less & $\begin{array}{l}10 \text { or } \\
\text { less }\end{array}$ & 0.2 & 3 \\
\hline $\mathrm{COD}(\mathrm{mg} / \mathrm{L})$ & 4 & 4 & - & - & 4 & 4 \\
\hline $\begin{array}{l}\text { Ammonia } \\
\text { (mg/L) }\end{array}$ & 0.5 & 0.5 & 1.2 & - & 0.5 & - \\
\hline $\begin{array}{l}\text { Nitrate } \\
\text { (mg/L) }\end{array}$ & 10 & - & - & - & 10 & - \\
\hline TDS (mg/L) & 1000 & $\begin{array}{l}500- \\
1000\end{array}$ & - & 2000 & 1000 & - \\
\hline TSS (mg/L) & 10 & 10 & - & - & - & - \\
\hline $\mathrm{TS}$ (mg/L) & - & $\begin{array}{l}20- \\
500\end{array}$ & - & - & - & - \\
\hline $\begin{array}{l}\text { Turbidity } \\
\text { (JTU) }\end{array}$ & 10 & $<29$ & - & - & 28 & - \\
\hline
\end{tabular}

Source: ECR, 1997; Jahan, 2010 and Reza, 2016 


\subsection{Health Risk Assessment by Dermal Absorption}

The dermal absorption is common by surface water exposure [12]. The expression for risk assessment is given as follows:

$C D I_{\text {derm }}=\left(C_{\mathrm{w}} * \mathrm{SA}^{*} \mathrm{C} \mathrm{F}^{*} \mathrm{PC} * \mathrm{ABS} * \mathrm{ET} * \mathrm{EF} * \mathrm{ED}\right) /(\mathrm{BW} * \mathrm{AT})$ where $\mathrm{CDI}=$ chronic daily intake, $\mathrm{SA}=$ surface area available for contact (cm 2 ), $\mathrm{CF}=$ volumetric conversion factor ( $\mathrm{L}$ to $\mathrm{cm} 3$ ), $\mathrm{PC}=$ metal or pollutant sp. dermal permeability constant, $E T=$ exposure time (hr), ABS = absorption factor (\%), Cw = metal or pollutant concentration in water in $\mathrm{mg} / \mathrm{l}, \mathrm{EF}=$ exposure frequency (days/yr), BW = body weight in $\mathrm{kg}, \mathrm{AT}=$ average time (days) and $\mathrm{ED}=$ exposure duration in year.

(Dry period)

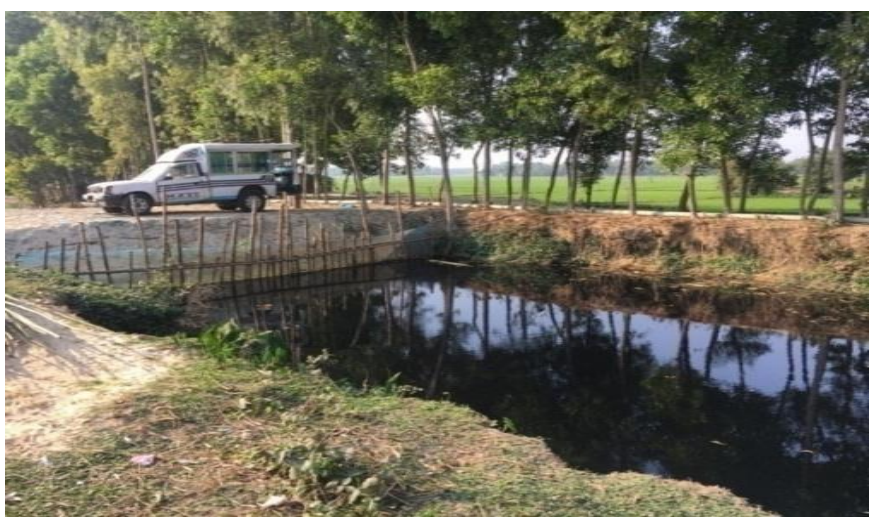

\subsection{RESULTS AND DISCUSSION}

During field survey it has been observed that the industries established just on the bank of streams discharge their untreated effluent directly into the streams near W2, W5 and W9. Effluent of $W 2$ and $W 5$ flow downstream and then accumulate with the stream water near W3 where an embankment impedes the water to flow downstream during dry season. But in monsoon, the authority of the industry lets the water flowing along with the effluent by cutting off the embankment (Figure 1). This unwise activity, ultimately, allows the effluent spreads through the drainage network and enters into the agricultural lands and rural settlement areas located in downstream causing changes in the concentrations of water quality parameters of different water bodies.

Concentration values of different water quality parameters found from physico-chemical analysis of water collected from fourteen sampling sites have been presented here (in Table 3). The parameters exceeding permissible li mits are indicators of pollution.

Figure 1 The presence and absence of the embankment near sample site W3 in two separate seasons (Source: Field Survey, 2019) 
Table 3 Concentrations of different parameters of water samples

\begin{tabular}{|c|c|c|c|c|c|c|c|c|c|c|c|c|c|c|c|}
\hline \multicolumn{2}{|l|}{ Stations } & W1 & W2 & W3 & W4 & W5 & W6 & W7 & W8 & W9 & W10 & $\overline{\text { W11 }}$ & W12 & W13 & W14 \\
\hline \multicolumn{16}{|l|}{ Parameters } \\
\hline \multirow[t]{2}{*}{$\mathrm{DO}(\mathrm{mg} / \mathrm{L})$} & Dry & 6.7 & 4.9 & 2.4 & 9.2 & 2.9 & 9.1 & 4.5 & 8.3 & 2.9 & 5.9 & 6.8 & 7.8 & 6.3 & 8.9 \\
\hline & $\begin{array}{l}\text { Mons } \\
\text { oon }\end{array}$ & 7.5 & 7.2 & 4.5 & 10.2 & 4.4 & 4.6 & 4.2 & 5.4 & 3.2 & 7.7 & 6.5 & 7.5 & 5.1 & 5.3 \\
\hline \multirow{2}{*}{$\begin{array}{l}\text { BOD } \\
(\mathrm{mg} / \mathrm{L})\end{array}$} & Dry & 0.4 & 0.3 & 2.2 & 1.9 & 2.5 & 0.5 & 0.7 & 0.7 & 2.7 & 4.8 & 0.6 & 2.1 & 0.9 & 1 \\
\hline & $\begin{array}{l}\text { Mons } \\
\text { oon }\end{array}$ & 0.2 & 0.1 & 1 & 1.7 & 0.7 & 1.1 & 0.3 & 0.9 & 1.1 & 2.4 & 0.2 & 0.8 & 0.2 & 0.2 \\
\hline \multirow{2}{*}{$\begin{array}{l}\text { COD } \\
(\mathrm{mg} / \mathrm{L})\end{array}$} & Dry & 2.1 & 4.5 & 33 & 3.5 & 47 & 8.5 & 9.8 & 2 & 450 & 12 & 5 & 6.5 & 8.3 & 9.6 \\
\hline & $\begin{array}{l}\text { Mons } \\
\text { oon }\end{array}$ & 3.5 & 3.2 & 4.6 & 3.3 & 8.7 & 8 & 7 & 3.6 & 275 & 6.3 & 5.1 & 4.3 & 4.4 & 8.5 \\
\hline \multirow[t]{2}{*}{$\mathrm{pH}$} & Dry & 6.36 & 6.02 & 6.17 & 6.23 & 6.78 & 7.93 & 7.13 & 6.27 & 7.53 & 7.16 & 7.24 & 7.29 & 7.52 & 7.79 \\
\hline & $\begin{array}{l}\text { Mons } \\
\text { oon }\end{array}$ & 6.35 & 6.05 & 6.39 & 6.5 & 7.05 & 6.16 & 6.32 & 6.23 & 7.45 & 6.79 & 6.45 & 6.53 & 6.39 & 7.03 \\
\hline \multirow{2}{*}{$\begin{array}{l}\text { Ammonia } \\
(\mathrm{mg} / \mathrm{L})\end{array}$} & Dry & 0.21 & 0.1 & 9.33 & 1.31 & 81.5 & 3.6 & 0.59 & 0.37 & 28.67 & 25.86 & 0.24 & 3.36 & 0.39 & 1.15 \\
\hline & $\begin{array}{l}\text { Mons } \\
\text { oon }\end{array}$ & 1.39 & 1.05 & 2.21 & 0.32 & 2.18 & 2.34 & 1.4 & 0.41 & 0.39 & 0.22 & 0.09 & 0.19 & 0.22 & 0.58 \\
\hline \multirow{2}{*}{$\begin{array}{l}\text { Nitrate } \\
\text { (mg/L) }\end{array}$} & Dry & 1.4 & 0.9 & 3 & 4.6 & 25.8 & 0.4 & 2.6 & 0.5 & 34.28 & Nil & 1.1 & 2.1 & 0.5 & 4.4 \\
\hline & $\begin{array}{l}\text { Mons } \\
\text { oon }\end{array}$ & Nil & 0.7 & Nil & Nil & Nil & 0.3 & Nil & 0.7 & 2.8 & Nil & 0.6 & 1 & 0.1 & 0.1 \\
\hline \multirow[t]{2}{*}{$\begin{array}{l}\text { T.D.S } \\
\text { (mg/L) }\end{array}$} & Dry & 0.1 & 1.73 & 0.91 & 0.18 & 1.47 & 2.27 & 2.27 & 1.08 & 1.7 & 2.45 & 2.93 & 1.59 & 0.37 & 0.29 \\
\hline & $\begin{array}{l}\text { Mons } \\
\text { oon }\end{array}$ & 0.18 & 0.18 & 0.18 & 2.28 & 2.46 & 1.54 & 0.1 & 0.1 & 0.1 & 0.2 & 0.1 & 0.1 & 0.1 & 0.1 \\
\hline \multirow{2}{*}{$\begin{array}{l}\text { T.S.S } \\
\text { (mg/L) }\end{array}$} & Dry & 0.04 & 0.01 & 0.09 & 0.02 & 0.29 & 0.01 & 0.02 & 0.17 & 0.1 & 0.01 & 0.08 & 0.07 & 0.11 & 0.13 \\
\hline & $\begin{array}{l}\text { Mons } \\
\text { oon }\end{array}$ & 0.19 & 0.12 & 0.02 & 0.02 & 0.02 & 0.02 & 0.01 & 0.01 & 0.02 & 0.01 & 0.01 & 0.01 & 0.01 & 0.03 \\
\hline \multirow[t]{2}{*}{ T.S (mg/L) } & Dry & 0.06 & 1.74 & 1 & 0.2 & 3.93 & 2.28 & 2.37 & 1.25 & 1.8 & 2.46 & 3.01 & 1.66 & 0.48 & 0.42 \\
\hline & $\begin{array}{l}\text { Mons } \\
\text { oon }\end{array}$ & 0.37 & 0.3 & 0.2 & 1.49 & 2.48 & 2.28 & 1.56 & 0.11 & 0.12 & 0.21 & 0.11 & 0.11 & 0.11 & 0.13 \\
\hline \multirow{2}{*}{$\begin{array}{l}\text { Turbidity } \\
\text { (JTU) }\end{array}$} & Dry & 13.35 & 15.75 & 14.48 & 13.07 & 17.07 & 10.81 & 40.77 & 14.43 & 13.71 & 14.11 & 15 & 13.33 & 16.43 & 14.97 \\
\hline & $\begin{array}{l}\text { Mons } \\
\text { oon }\end{array}$ & 208 & 15.29 & 134 & 160 & 117 & 113 & 59 & 18.12 & 1.59 & 8.16 & 20 & 10.84 & 2.57 & 16.4 \\
\hline
\end{tabular}

\section{Potential of Hydrogen (pH)}

$\mathrm{pH}$ is an important factor that determines the suitability of water for different purposes [24]. The $\mathrm{pH}$ values of sample sites W1, W2, W3 and W8 are below the standard in all seasons.
Lower $\mathrm{pH}$ also found in rural settlement areas (sample sites W6, W7, W8, W11 and W13) in monsoon season indicate s the spread of acidification due to the cutting off the embankment causing damage to aquatic ecosystems (Figure 2 ).

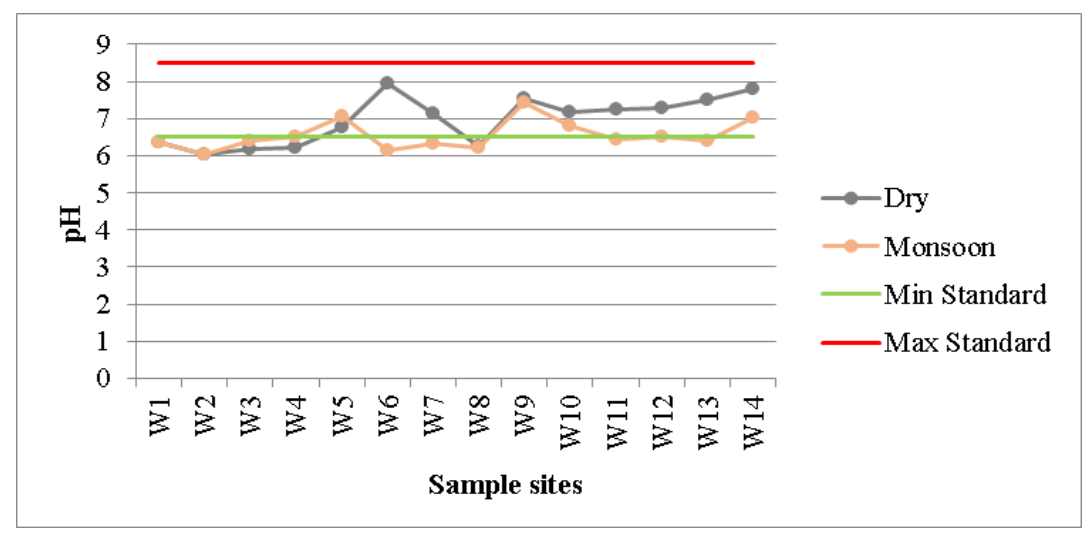

Figure $2 \mathrm{pH}$ value of water samples (

Source: Laboratory analysis, 2019) 


\section{ii Dissolved Oxygen (DO)}

DO is one of the most important factors in stream health [22].

Oxygen deficiency directly affects the ecosystem of rivers due to bioaccumulations and bio magnifications [7]. In current study, sample sites having DO value less than $5 \mathrm{mg} / \mathrm{L}$ are not usable for any purpose (Figure 3).

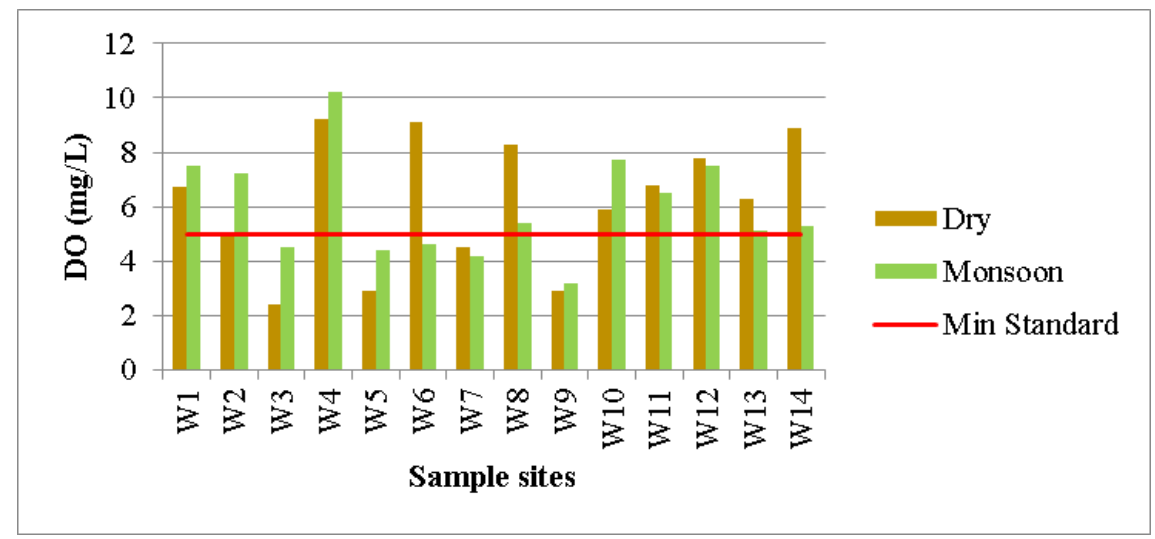

Figure 3 DO of water samples

(Source: Laboratory analysis, 2019)

It is clear from a local survey that soil near the bank of stream turned into blackish due to water pollution. As a result, ro ot of the plants near the stream got rotten and consequently the plant died. The local inhabitants also claimed the polluted water for the damage of the crops and death of the fisheries [13]. It will be worth mentioning that industry located near W5 is not responsible for water contamination of sample site W9 as it is being polluted by a textile industry on its bank.

\section{iii Biochemical Oxygen Demand (BOD 5$)$}

$\mathrm{BOD}_{5}$ is a strong indicator of the level of organic pollution in the river [7]. High $\mathrm{BOD}_{5}$ value indicates the presence of organic pollutants that cause oxygen depletion in the water.

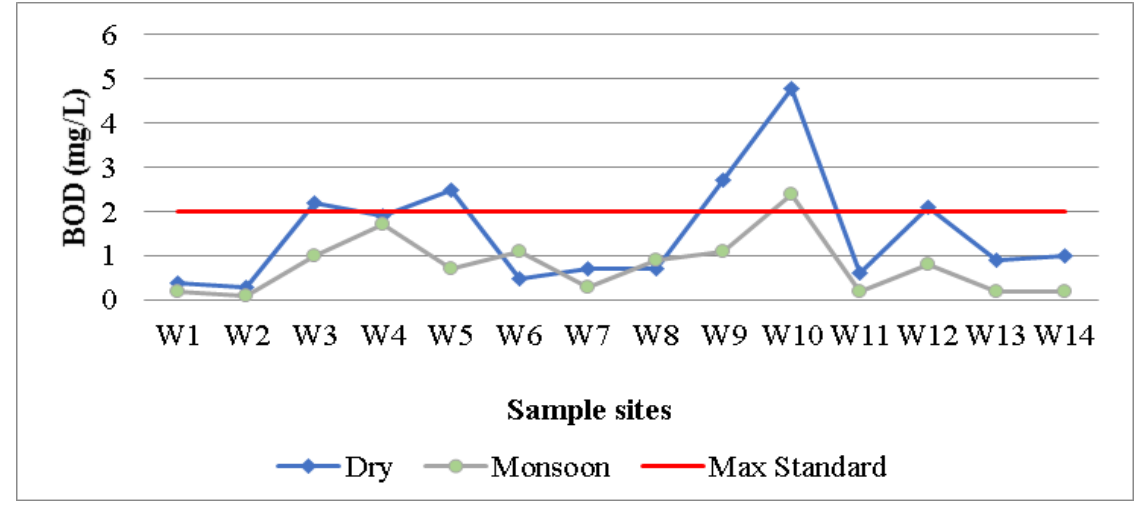

Figure 4: BOD5 of water samples

(Source: Laboratory analysis, 2019)

As the mean $\mathrm{BOD}_{5}$ value is greater than the standard value for drinking purpose $(0.2 \mathrm{mg} / \mathrm{L})$, water of streams is not drinkable (Figure 4). It can be used for irrigation, fisheries and other purposes.

\section{iv Chemical Oxygen Demand (COD)}

COD is commonly used to indirectly measure the amount of organic compounds in water [24]. From the laboratory analysis it has been revealed that water of downstream is highly polluted and not suitable for any purpose (Table 2 and Table 3 ). 


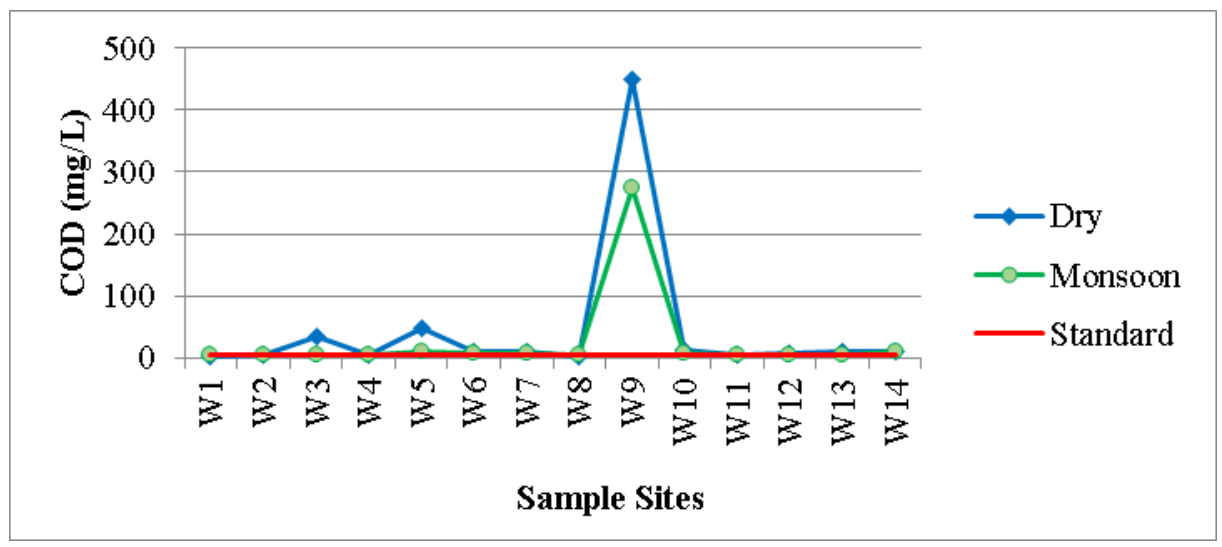

Figure 5 COD of water samples

(Source: Laboratory analysis, 2019)

The high COD value in $W 9$ is an indication of large amount of organic matter in the water due to the gross chemical load of the effluent discharging into the stream and eventually water becomes contaminated (Figure 5).

\section{$v$ Ammonia $\left(\mathrm{NH}_{3}-\mathrm{N}\right)$}

As ammonium hydroxide, sulphuric acid, sodium bisulfate etc. are used in the production of starch; the effluent consists of proteineous matter, settable matter, sulphide, $\mathrm{SO}_{2}$, ammonia etc. [19].The highest concentration of ammonia $(81.5 \mathrm{mg} / \mathrm{L})$ found at W5 during dry season, gives an indication that the industry might have involved in starch production (Table 2 and Figure 6). The concentration beyond the permissible limit also implies that the water of those sites is contaminated and is not suitable for drinking and fish cultivation. Though ammonia and nitrate are the most common forms of nitrogen in aquatic systems; the high concentration of neutral, un-ionized ammonia can cause the loss of fisheries as well as live stock since it is highly toxic to all aquatic lives and terrestrial livestock. Besides, high concentration of ammonia can cause the death of plants and damage of crops by lowering the reproduction and growth of plants.

\section{vii Nitrate}

The distribution of nitrate related compounds indicates levels of concentration of ions are very high compared to permissible limits. Impurity with nitrate in downstream water mainly

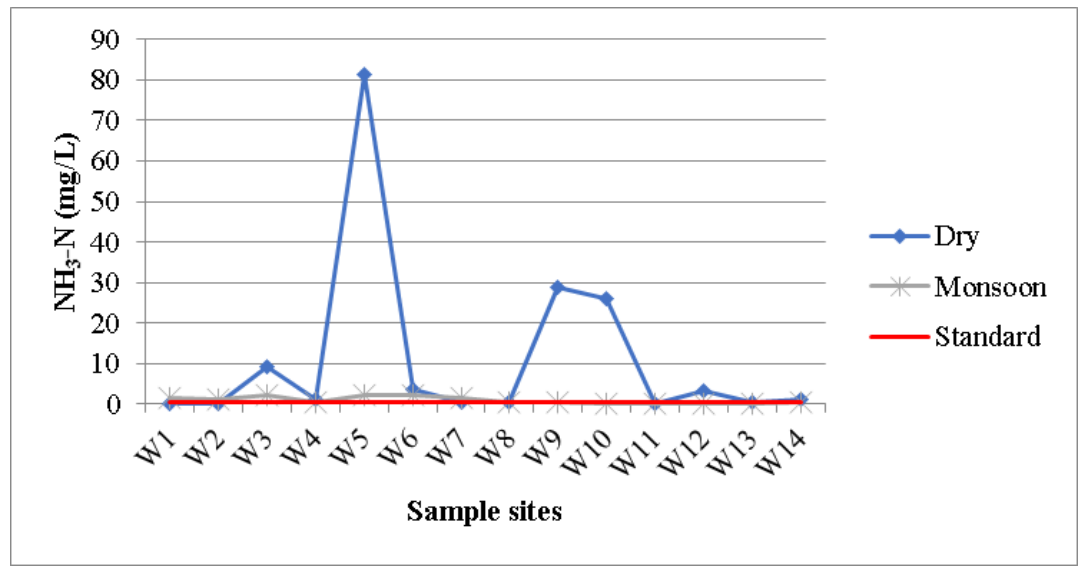

Figure 6 Ammonia of water samples

(Source: Laboratory analysis, 2019)

occurs in dry season making it undrinkable and in monsoon pollutants are diluted with rain water (Figure 7).The concentration of nitrate $(25.8 \mathrm{mg} / \mathrm{L})$ exceeds the permissible limit in sample site W5 while the concentration has al so be en found as $34.28 \mathrm{mg} / \mathrm{L}$ in $\mathrm{W} 9$ where a textile industry discharges their effluent. Similar distribution of nitrate related compounds of samples was observed by Gajendran [10] in Nanbiyar river basin due to food industrial zone in India. 


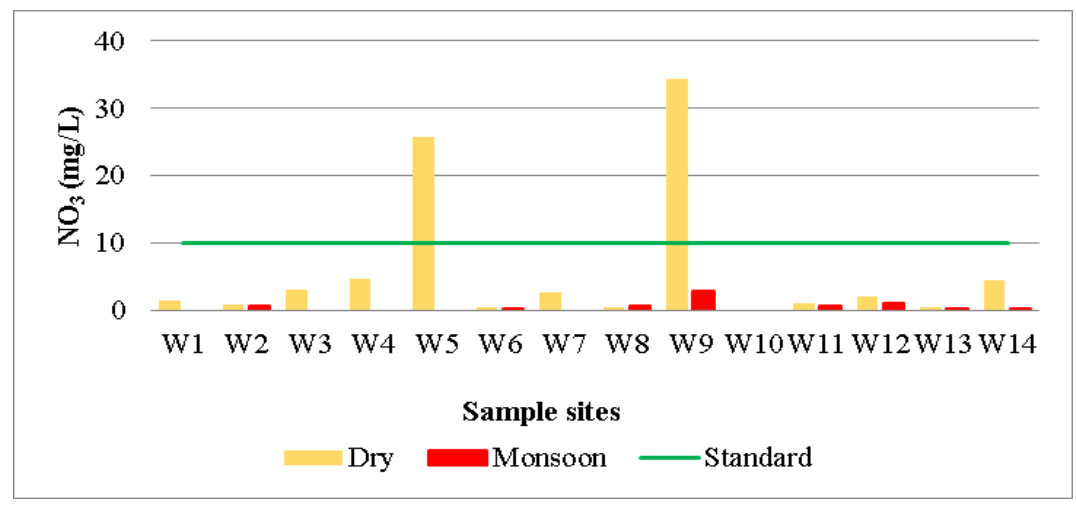

Figure 7: Nitrate of water samples

(Source: Laboratory analysis, 2019)

Usually, nitrate is a natural constituent of the human diet like maize, wheat, barley etc. and an approved food additive [11]. Moreover, it is also found in arrowroot waste fiber used in textile materials [6].The starch and agro-feed industries use potatoes, maize, wheat and tapioca as their basic raw mate rial for starch production [8] and feed ingredients such as maize, wheat, barley, soybean meal, sunflower cake, rape seed meal, canola meal, wheat bran, deoiled rice bran etc. for the preparation of diet for poultry boilers and layers [21]. So, nitrate can be produced as a byproduct from poultry feed production and textile industry; and is mobile when soluble in water and can therefore be rapidly transported through the soil, reaching the ground water and contaminating drinking water supplies [16]. This implies that the industry near W5 is a starch and poultry feed production industry.

Besides all the above parameters, the turbidity value of W1, W3, W4, W5 and W6 is so high in monsoon while Total Dissolve Solid (T.D.S), Total Suspended Solid (T.S.S) and Total Solid (T.S) values are within the standard level ranging from 0.1 to $2.93 \mathrm{mg} / \mathrm{L}, 0.01$ to $0.29 \mathrm{mg} / \mathrm{L}$, and 0.2 to $3.93 \mathrm{mg} / \mathrm{L}$ respectively for the dry as well as monsoon season s(Table 3 ).

\subsection{WQI}

Conventional analysis of water quality parameters is too detailed, so it cannot be able to supply a comprehensive assessment of water quality. To overcome this gap, WQI is a suitable tool. WQI is considered as one of the criterion for the classifications of surface water, on the basis of the usage of standard parameters for water evaluation and characterization. It may provide an accurate perception about the pollution based on field survey or public opinion.

In current study, calculation of WQI is based on ten important physico-chemical parameters at fourteen different sites and an example calculation is presented in Table 4.WQI calculations for other sample sites are calculated accordingly and the WQI values have been presented in Table 5. Finally, the suitability of water has been evaluated based on WOI value following the schemes (Table 6) prescribed by Vasanthavigar et al. [25].

In this current study, the computed WQI values ranges from 24.9 to 720 during dry season whereas it ranges within 12.13 to 320 during monsoon season. Therefore, it can be categorized into five types "excellent water" to "water unsuitable for drinking and another purpose". The high value of WQI at these stations has mainly been found due to the higher values of ammonia and turbidity in the stream water. Table 6 shows the percentage of water samples that falls under different quality. During dry period, about $42 \%$ of water samples are "Unsuitable" in quality whereas $28.5 \%$ ranked as "Excellent" during monsoon. 
Table 4: An example calculation of WQI for the sample site Wl (Dry \& Monsoon)

\begin{tabular}{|c|c|c|c|c|c|c|c|c|c|c|}
\hline \multirow[t]{2}{*}{ Parameter } & \multicolumn{2}{|c|}{ Observed value (Vi) } & \multirow[t]{2}{*}{ Standard value (Si) } & \multirow[t]{2}{*}{ Ideal value (Vid) } & \multirow[t]{2}{*}{ kvalue } & \multirow{2}{*}{$\begin{array}{l}\text { Unit weight } \\
\text { (Wi) }\end{array}$} & \multicolumn{2}{|c|}{ Quality Rating (Qi) } & \multicolumn{2}{|l|}{$\mathrm{Qi}^{*} \mathrm{Wi}$} \\
\hline & Dry & Monsoon & & & & & Dry & Monsoon & Dry & Monsoon \\
\hline $\mathrm{pH}$ & 6.36 & 6.35 & $\begin{array}{l}6.5-8.5 \\
\text { mean }=7.5\end{array}$ & 7 & 0.3 & 0.04 & 128 & 130 & 5.12 & 5.2 \\
\hline DO & 6.7 & 7.5 & 5 & 14.6 & 0.3 & 0.06 & 82.29 & 73.95 & 4.93 & 4.43 \\
\hline BOD & 0.4 & 0.2 & 2 & 0 & 0.3 & 0.15 & 20 & 10 & 3 & 1.5 \\
\hline COD & 2.1 & 3.5 & 4 & 0 & 0.3 & 0.07 & 52.5 & 87.5 & 3.67 & 6.12 \\
\hline $\mathrm{NH}_{3}-\mathrm{N}$ & 0.21 & 1.39 & 0.5 & 0 & 0.3 & 0.6 & 42 & 278 & 25.2 & 166.8 \\
\hline $\mathrm{NO}_{3}$ & 1.4 & 0 & 10 & 0 & 0.3 & 0.03 & 14 & 0 & 0.42 & 0 \\
\hline TDS & 0.1 & 0.18 & 750 & 0 & 0.3 & 0.0004 & 0.01 & 0.02 & 0.000004 & 0.000008 \\
\hline TSS & 0.04 & 0.19 & 10 & 0 & 0.3 & 0.03 & 0.4 & 1.9 & 0.01 & 0.5 \\
\hline TS & 0.06 & 0.37 & 350 & 0 & 0.3 & 0.0008 & 0.02 & 0.1 & 0.00001 & 0.00008 \\
\hline Turbidity & 13.35 & 208 & 28 & 0 & 0.3 & 0.01 & 47.67 & 742.85 & 0.47 & 7.42 \\
\hline & & & & & & $\Sigma \mathrm{Wi}_{1}=1$ & & & $\begin{array}{l}Q^{i}{ }^{*} W_{1}= \\
42.82\end{array}$ & $\begin{array}{l}\sum \mathrm{Qi}^{*} \mathrm{Wi}= \\
191.97\end{array}$ \\
\hline
\end{tabular}

Source: Laboratory analysis, $2019 \quad$ **Sivalues are taken as per DOE \& ECR standard

Table 5 WQI values for all sample sites in two different seasons

\begin{tabular}{|l|l|l|}
\hline Sample sites & Dry season & Monsoon season \\
\hline W1 & 42.82 & 191.97 \\
\hline W2 & 36.80 & 143.77 \\
\hline W3 & 540 & 297.22 \\
\hline W4 & 184.45 & 69.41 \\
\hline W5 & 720 & 247.22 \\
\hline W6 & 441.6 & 320.13 \\
\hline W7 & 145.92 & 624.54 \\
\hline W8 & 102.37 & 115.39 \\
\hline W9 & 680 & 222 \\
\hline W10 & 610 & 28.57 \\
\hline W11 & 24.9 & 12.13 \\
\hline W12 & 411 & 33.13 \\
\hline W13 & 76 & 25 \\
\hline W14 & 136 & 58.84 \\
\hline & Source: Laboratory analysis, 2019 \\
\hline
\end{tabular}


Table 6 Water quality classification based on WQI value

\begin{tabular}{|l|l|l|l|}
\hline WQI Levels & Rating & \multicolumn{2}{l|}{ (\%) of Water Samples } \\
\cline { 2 - 4 } & & Dry & Monsoon \\
\hline$<50$ & Excellent & 21.43 & 28.5 \\
\hline $50-100$ & Good & 7.14 & 14.28 \\
\hline $100-200$ & Poor & 28.5 & 21.43 \\
\hline $200-300$ & Very poor (bad) & 0 & 21.43 \\
\hline$>300$ & Unsuitable (Unfit) & 42 & 14.28 \\
\hline
\end{tabular}

Source: Laboratory analysis, 2019

WQI is considered as the most effective tool for public understanding of pollution status of water. To generate changes in WQI along the study area, interpolation was used. Inverse distance weight (IDW) method was applied for interpolation. To predict a value for any unmeasured location, IDW uses the measured values surrounding the prediction location. Measured values which are the closest to the predicted location will have more influence on the predicted value than values at the outer most points. So, IDW assumes that each measured point has a local influence that diminishes with distance. IDW interpolation method determines cell values using a linearly weighted combination of a set of sample points. The weight is a function of inverse distance [14]. Figure 8 shows the spatial distribution of water quality in the study area.

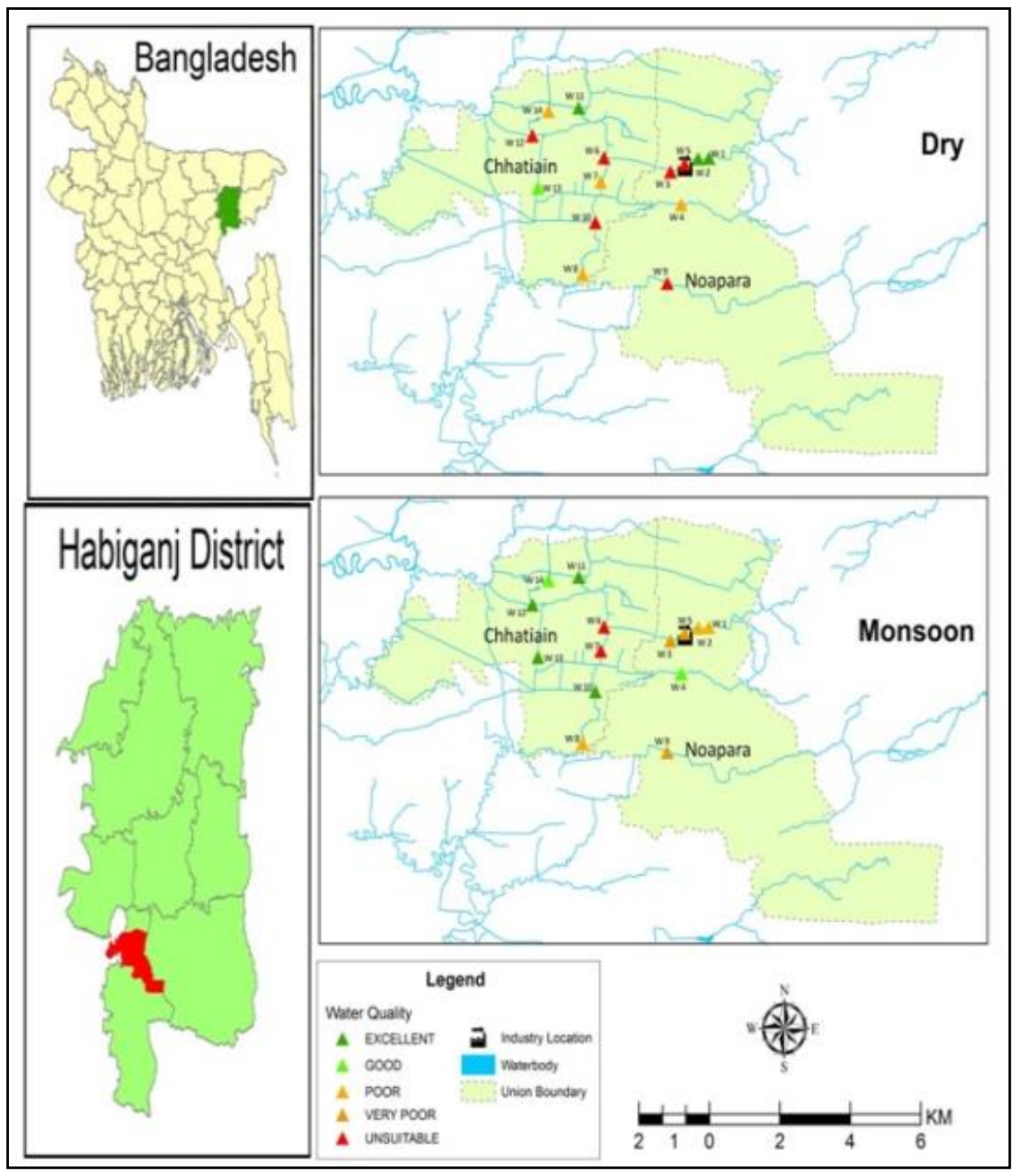

Figure 8 Seasonal Variation of WQI

(Source: Laboratory analysis, 2019) 


\subsection{Health Impact Based on WQI}

Low DO, high BOD and high nitrate concentration indicates the eutrophic status of the water body. A relatively higher concentration of Chlorides and Sulphates indicates unsuitability for domestic use [26]. Qualitative health risk due to polluted water can be evaluated from human exposure to pathogens of an individual. Human health risk is a function of direct ingestion and dermal absorption through skin exposure. But for polluted water, only dermal exposure is a matter of concern and he al th risk from dermal absorption is a function of dermal permeability, exposure time, exposure frequency etc. [9]. Since there is no study on the coefficient of exposure, exposure frequency and dermal permeability in our country, an in direct health risk is evaluated in this study following Table 7.

Table 7 Definition for classification of surface water quality

\begin{tabular}{|l|l|}
\hline WQI & Description \\
\hline WQI $<10$ & $\begin{array}{l}\text { Usually oxygen saturated, nutrient poor water, low bacteria } \\
\text { content }\end{array}$ \\
\hline WQI $<25$ & $\begin{array}{l}\text { Small amount of organic and inorganic nutrients without or } \\
\text { with slight oxygen depletion, low bacteria }\end{array}$ \\
\hline WQI $<40$ & $\begin{array}{l}\text { Not a good oxygen supply, inputs organic and inorganic } \\
\text { nutrients, presence of bacteria }\end{array}$ \\
\hline WQI $<75$ & $\begin{array}{l}\text { Usually low oxygen content, presence of micro-organisms, } \\
\text { periodic fish killing occurs }\end{array}$ \\
\hline WQI $>75$ & $\begin{array}{l}\text { Excessively polluted by organic oxygen depleting substances, } \\
\text { prolonged periods of very low oxygen concentrations, no fish } \\
\text { stocks, lots of bacterial life, cannot use for any purpose. }\end{array}$ \\
\hline
\end{tabular}

Source: Jafarabadi et al., 2016

Comparing the WQI values from Table 5 with Table 7 it is clear that water of those sites having WQI>75 is unfit for irrigation purpose and also unsuitable for laundry. CDI value for dermal absorption was evaluated using USEPA guidelines [23] based on following Table 8 and found the highest amount as $140 \mathrm{mg}$ and $150 \mathrm{mg}$ for children and adult respectively considering only the elements related with nitrate and ammonia. It should be compared to WHO recommended ADI (Acceptable Daily Intake). If it is less than the ADI value, he al th risk will be insignificant. But cumulative effects of pollutants should be assessed before concluding any comment.

Table 8 Standard values for assessment of dermal absorption

\begin{tabular}{|l|l|l|l|l|l|}
\hline Variable & Children & Adult & Variable & Children & Adult \\
\hline SA. $\mathrm{cm}^{2} /$ event & 5140 & 10,000 & ED in yrs & 5 & 15 \\
\hline ABS (unit-less) & 1 & 1 & BW in kg & 13.2 & 70 \\
\hline ET hrs/day & 8 & 20 & AT in days & $365^{*}$ ED & $365^{*}$ ED \\
\hline EF days/hr & 225 & 225 & & & \\
\hline
\end{tabular}

Source: USEPA Handbook, 2001

\subsection{CONCLUSION}

The presence of nitrate in the effluent discharged to the stream water is clear evidence that the industry near sample site W5 produces corn starch and poultry feed. Besides nitrate, ammonia is found as a byproduct in the effluent of which so me portion exists as free nitrogen and/or ammonia in aquatic medium, some portion transform into nitrate and some portion release to atmosphere in gaseous form. The lower DO values
$(2.4 \mathrm{mg} / \mathrm{L}-4.5 \mathrm{mg} / \mathrm{L})$ in relation to both DoE and ECR standards indicate that water from sample sites-W3, W5, W7, W9 in dry season and sample site $W 6$ in monsoon season is not suitable for any purpose which is one of the reasons for loss of fisheries, livestock deaths and crop damage. According to WQI, during dry period, about $42 \%$ water samples are "Unsuitable" whereas 28.5\% as "Excellent" during monsoon. Pollution intensity is higher in dry season rather than monsoon. In monsoon, 
effluent mix with rain water and extent of pollution spreads over a large area.

In conclusion, it has been revealed that the corn starch and poultry feed processing industry situated in Noapara uni on is contaminating water of its adjacent areas which is ultimately responsible for creating different types of problems of the local community. Though this study is an attempt to address those problems and investigate the causes behind the problems, it has been felt that more comprehensive researches are required on this issue.

\section{Acknowledgements}

This research work was supported by a grant from NST Fellowship program of 2018-2019 FY awarded by Ministry of Science and Technology, Government of the People's Republic of Bangladesh and the Tanje-Un-Jenat was the recipient. The authors would like to acknowledge Tahmid Anam Chowdhury, a post-graduate student at Geography and Environment in Shahjalal University of Science and Technology for his continuous support in the preparation of map.

\section{References}

[1] Alexander K. C. 1976 Limnological Studies of Upper Lake and Lower Lake of Bhopal, Ph. D thesis, Vikram University, Ujjain.

[2] Alam, Md. J.B., Muyen, Z., Islam, M. R., Islam, S. and Mamun, M. "Water Quality Parameters along Rivers", International Journal of Environmental Science \& Technology. 4(1): 159-167, 2007

[3] Ahamed, S., David, K.S. and Gerald, S. 2004 "Environmental Assessment: An Innovation Indeed for Evaluation Water Quality in Streams", Environmental Management. 34:406-414,

[4] American Public Health Association (APHA), American Water Works Association (AWWA) 1995. "Standard Method for Analysis of Water and Waste Water, 19th Edition.

[5] Aigberua, A., and Tarawou, T. 2019. Water Quality Index (WQI) Assessment along Inland Fresh Waters of Taylor Creek in Bayelsa State, Nigeria. Journal of Environmental Treatment Techniques. 7(3): 260-269.

[6] Capina, M.V., and Capina, V.L.L. 2017. Arrowroot (MarantaArundinacea): Starch Extraction, Processing, and By-Products Utilization. Paper presented at the 4th International Conference on Civil, Environment and Waste Management (CEWM-17). Retrieved from https://link.springer.com/article/10.1007/BF02859011. Accessed on March. 20, 2019

[7] Davie, T. 2008. Fundamentals of Hydrology. Routledge

[8] Ellis, R. P., Cochrane, M. P., Dale, M. F. B., Duffus, C. M., Lynn, A., Morrison, I. M., and Tiller, S. A. 1998. Starch Production and Industrial Use. Journal of the Science of Food and Agriculture. 77(3): 289-311.

[9] Edokpayi, J. N., Enitan, A. M., Mutileni, N., and Odiyo, J. O. 2018 Evaluation of Water Quality and Human Risk Assessment Due to Heavy Metals in Groundwater around Muledane Area of Vhembe District, Limpopo Province, South Africa. Chemistry Central Journal, 12(1), 2

[10] Gajendran, C., 2011. "Water Quality Assessment and Prediction Modeling of Nambiyar river Basin, Tamil Nadu, India", Ph. D thesis, Department of Civil Engineering, Anna University
[11] Habermeyer, M., Roth, A., Guth, S., Diel, P., Engel, K. H., Epe, B., and Knorr, D. 2015. Nitrate and Nitrite in the Diet: How to Assess Their Benefit and Risk for Human Health. Molecular Nutrition and Food Research. 59(1): 106-128.

[12] Hossain, M.R. and Hassan, K.M. 2019. "Risk Assessment of Solid Waste Disposal on Ground Water Quality Around Rajbandh Dumping Place", Watersafe-2019.

[13] Jahan, N. and Islam, M.T. 2018. Impact of Industrial Pollution: A Perception Study in Madhabpur, Habiganj. Stamford Journal of Environment and Human Habitat. 7: 67-76

[14] Jafarabadi, R. A., Masoodi, M., Sharifiniya, M., and RiyahiBakhtiyari, A. 2016. Integrated River Quality Management by CCME WQI as an Effective Tool to Characterize Surface Water's Pollution (Case study: Karun River, Iran). Pollution. 2(3): 313-330.

[15] Jafaradesh, N.; Rostami, S.; Sepehrfar, K. and Lahijanzudesh, A. 2004 "Identification of the Water Pollutant Industries in Khuzestan Province", Iranian Journal of Environmental Health Science Engineering. 1(2)

[16] [16] Oviedo-Rondón EO 2008 Tecnologias Para Mitigar o ImpactoAmbiental Da Produção de Frangos de Corte. RevistaBrasileira de Zootecnia 37:239-252.

[17] [17] Pawar, C. T. and Joshi M. V. 2002 "Impact of Urbanization and Industrialization on Water Quality", Natural Environmental Pollution Technology, 4(1)

[18] Khwakaram, A. I.; Majid, S. N.; Ahmed, Z. H,; Hama, N. 2015. "Application of WQI as a Possible Indicator for Agriculture Purpose and Assessing the Ability of Self-Purification Process by Qalyasan Streams in Solaimani city/IKR" International Journal of plant, Anima and Environmental Sciences (IJPAES), 5 (1)

[19] Khambe, S. 2015. Treatment of Waste Water in Corn Starch Industry. Retrieved from https://www.academia.edu/9124978/TREATMENT_OF_WASTE_WAT ER_IN_CORN_STARCH_INDUSTRY accessed on September 14, 2017.

[20] Reza, A., and Yousuf, T. B. 2016. Impacts of Waste Dumping on Water Quality in the Buriganga River, Bangladesh and Possible Mitigation Measures. Journal of the Environment. 11(1): 35-40.

[21] Swain, B. K. 2015. Role of Enzymes as Feed Additives in Poultry Production. Retrieved from https://www.researchgate.net/publication/282656562_Role_of_Enz ymes_as_Feed_Additives_in_Poultry_Production, accessed on Oct. $20,2019$.

[22] Trivedi, R. 2008. Water Quality Management in India.3rd International Conference on Water Quality Management. 1-22. Nagpur, India.

[23] United State Environmental Protection Agency (USEPA). 2001. "Hand Book" Inderscience Publishers Limited

[24] Venkatesharaju, K., Ravikumar, P., Somashekar, R. K., and Prakash, K. L. 2010. Physico-chemical and Bacteriological Investigation on the River Cauvery of Kollegal Stretch in Karnataka. Kathmandu University Journal of Science, Engineering and Technology. 6(1):50-59.

[25] Vasanthavigar, M., Srinivasamoorthy, K., Vijayaragavan, K., Ganthi, R. R., Chidambaram, S., Anandhan, P., and Vasudevan, S. 2010. Application of Water Quality Index for Groundwater Quality Assessment: Thirumanimuttar Sub-basin, Tamilnadu, India. Environmental Monitoring and Assessment. 171(1-4): 595-609.

[26] Yogendra, K., and Puttaiah, E. T. (2008). Determination of WQI and Suitability of an Urban Waterbody in Shimoga Town, Karnataka. In Proceedings of Taal 2007: The 12th World Lake Conference. 342- 346. 